\title{
Escolas Médicas
}

"A noção de autonomia universitária não pode ser confundida com a de independência. A sociedade deseja médico que saiba medicina, que tenha se preparado cientificamente para cuidar da saúde do povo e que não seja, pela precariedade do ensino improvisado na industrialização de diplomas, ameaça à vida do paciente." (Saulo Ramos, Jurista, 1988)

O Sr. Ministro da Saúde, Humberto Costa, em resolução publicada no D.O. da União de 15 de julho de 2003, acatou a decisão do plenário do Conselho Nacional de Saúde recomendando a suspensão por 180 dias de novas autorizações para abertura de cursos superiores na área da saúde. Visa a resolução evitar abertura indiscriminada de novos cursos mormente em regiões já supersaturadas.

O jornal da FEBRASGO, de abril de 2003, elaborou magnífica sintese sobre o mercado de trabalho médico no Brasil. Grandes distorções ficam patentes à análise do documento. Além do excessivo número de profissionais, em avesso do que recomenda a OMS, verifica-se total desajuste na distribuição geográfica dos mesmos. A região sudeste alberga $59,4 \%$ da totalidade dos médicos. E é justamente nesta área que multiplicam-se os pedidos e, não sabemos explicar por que, abrem-se efetivamente novos cursos.

O Conselho Regional de Medicina do Estado de São Paulo confeccionou excelente fascículo sobre o tema: "Por que somos contra a abertura de novos cursos de Medicina". Aborda com precisão as questões pertinentes e mostra, à saciedade, o desastre da abertura de novos cursos e os interesses velados de grupos dissociados do real interesse da medicina, dos pacientes e do País.

Com esta realidade epidêmica de abertura de novos cursos de medicina indagamo-nos: "Existe capacidade de absorção destes mais de 10 mil diplomados por ano? Não necessitam eles complementação para o dificil e sagrado exercício da medicina? A residência médica não é hoje indispensável para a formação destes médicos? Estas escolas recém implantadas preocupam-se com esta formação? Não deve o Governo intervir no interesse de toda a nação?

Sabemos que somente 30\% dos diplomados conseguem vaga para os cursos de complementação na residência médica. Como então permite o Governo esta avalanche de novos cursos? Não há interesse de grupos econômicos, fortes, que visam muitas vezes exclusivamente, o lucro na educação?

O momento exige ação rápida e universal para reversão do quadro evitando-se futuras catástrofes.

A Diretoria 